$1-1-1963$

\title{
Black cherry: its abundance, quality, and rate of growth in oak-hickory and cove forests of West Virginia
}

\author{
Kenneth L. Carvell \\ C. B. Knoch
}

Follow this and additional works at: https://researchrepository.wvu.edu/ wv_agricultural_and_forestry_experiment_station_bulletins

\section{Digital Commons Citation}

Carvell, Kenneth L. and Knoch, C. B., "Black cherry : its abundance, quality, and rate of growth in oak-hickory and cove forests of West Virginia" (1963). West Virginia Agricultural and Forestry Experiment Station Bulletins. 485.

https://researchrepository.wvu.edu/wv_agricultural_and_forestry_experiment_station_bulletins/455 @ WVU. It has been accepted for inclusion in West Virginia Agricultural and Forestry Experiment Station Bulletins by an authorized administrator of The Research Repository @ WVU. For more information, please contact ian.harmon@mail.wvu.edu. 
Vin

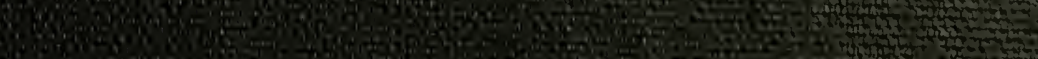

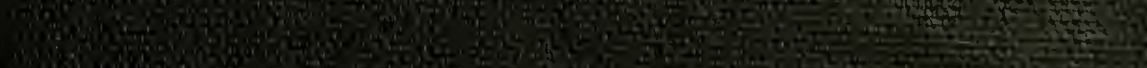
9ro

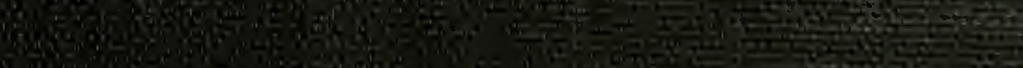
W0

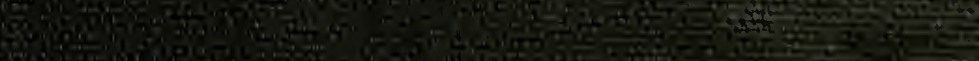

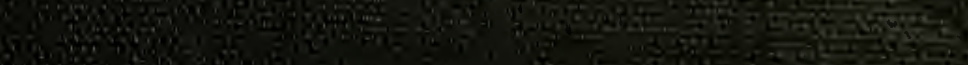

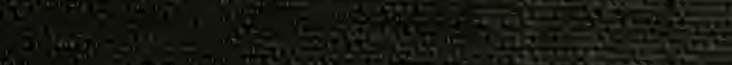
No Xign

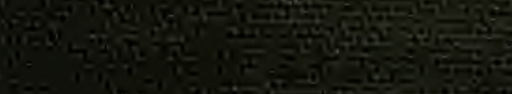
\%

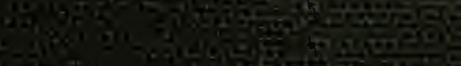


Digitized by the Internet Archive in 2010 with funding from

Lyrasis Members and Sloan Foundation 


\section{Summary}

A study of the occurrence, abundance, quality, and growth rate of black cherry in oak-hickory and cove types in northern West Virginia was made to determine those aspects and slope positions on which the best black cherry trees occur, and discover some of the factors which influence stem quality.

Basal area per acre for all species was broken down by aspect and slope position. Total basal area per acre varied from 82.7 square feet on the cool, moist aspects (north-, east-, and northeast-facing slopes) to 59.1 square feet on the warm, dry aspects (south-, west-, and southwest-facing slopes). Intermediate aspects (northwest- and southeastfacing slopes) compared favorably in basal area with cool, moist slopes. The largest basal areas per acre occurred on the middle-third slope positions.

The number of sprout black cherry with superior stem quality (no defects or one minor defect in the first $\log$ ) increased as the total basal area per acre increased. This was attributed partly to the higher stocking on these sites, resulting in better natural pruning and less forking, and partly to the similarity in rate of height growth of seedlingand sapling-sized cherry and their associates on the better sites. On the drier sites, where the lower basal areas were characteristic, the fast-growing sapling cherry usually tower well above the neighboring trees, resulting in forking and coarse branching.

The number of high-quality cherry stems varied from 16 per acre on moist, cool aspects to less than 1 per acre on warm, dry aspects. On the basis of slope position, the largest concentration of superior cherries was found on the middle-third slope, and the lowest on the upper-third slope.

Dominant black cherry and yellow-poplar displayed more rapid diameter growth than northern red oak on all sites except the south, west, and southwest exposures. On the dry, warm exposures northern red oak growth was more rapid than that of cherry.

The glaze belt occurred above 1,850 feet elevation on the cooler exposures and above 2,000 feet on the warmer exposures. Although 24.4 per cent of the cherries within the glaze belt showed moderate to severe breakage, the frequency of glaze storms in this area does not seem to justify restricting management for black cherry within this zone.

Thus, within the oak-hickory and cove types, because of sheer numbers and bole quality, management for black cherry must be concentrated on the more moist, cooler sites, particularly on the lower two-thirds of the moist, cool aspects and on the intermediate aspects. Even on the warm, dry slopes, however, an occasional cherry of good form is encountered. When these are found, they must be encouraged through intermediate cuttings, since their rapid growth and potential value far exceeds that of other species characteristic of these positions.

W'fest T'yrginia UNiversity Agricultural Experimext Station College of Arriculture, Forestry, and Hove Econouics MORGANTOWN-A. H. VANLANDINGHAM, DIRECTOR 


\section{BLACK CHERRY}

\section{Its Abundance, Quality, and Rate of Growth in the Oak-Hickory and Cove Forests of West Virginia}

\section{K. L. CARVELL and C. B. KOCH}

M UCH of the forest acreage in West Virginia supports pole-sized, evenaged stands of the oak-hickory or cove hardwood type. Many of these are of sprout origin, developing naturally following the complete removal of young stands for small wood products at the turn of the century.

Others have developed from seed following cuttings in older stands. Although yellow-poplar (Liriodendron tulipifera L.) and various oaksnorthern red (Quercus rubra L.), white (Quercus alba L.), chestnut (Quercus prinus L.), and scarlet (Quercus coccinea Muenchh.) -make up the largest percentage of these stands, many other commercial species are scattered throughout. The distribution of these associates is not at random. Their occurrence and abundance is related either to a combination of physiographic factors such as slope position, aspect, and per cent slope, or to past land use and wildfire history.

Black cherry (Prumus serotina Ehrh.) and black waInut (Juglans nigra L.) are the most valuable species of the Appalachian hardwood forests. The occurrence of a few merchantable stems of these species per acre can greatly raise the value of the timber harvest. With the possible exception of black walnut, black cherry is the most desirable cabinet wood in the United States. It is also of major importance in the manufacture of printers' blocks, patterns, professional and scientific instruments, and numerous other products.

Even the common grades of cherry lumber command prices comparable to, or in excess of, those paid for Firsts and Seconds and Select grades of many other species. It is significant that many of the products for which cherry is particularly desirable do not require clear boards of large size; thus trees with poorly-developed boles, if properly utilized can have values considerably greater than now realized. The high value of even the lower grades of cherry suggests that it may be more profitable to manage poorly-formed black cherry, at least on certain sites, than to remove it and favor straight-boled trees of other species.

Excellent black cherry, as good as any in the eastern United States, is found within the limited area of northern hardwood forests of W'est Virginia. These forests cover slopes with rich, moist, loamy soils, mostly

The authors are Kenneth L. Carvell Associate Experiment Station Silviculurist and Christian B. Koch, Assistant Experiment Station Forester. 
in a zone between 3,000 and 4,000 feet elevation. The largest concentration of northern hardwoods in this State is found in Tucker, Randolph, Nicholas, Pocahontas, Webster, and Greenbrier counties. However, the total acreage of northern hardwoods in West Virginia is only 1.5 million acres, 15 per cent of the State's total commercial forest area (Wray, 1952).

A study entitled "Utilization and Management of Sprout Black Cherry" was initiated in 1959 by foresters at the West Virginia University Agricultural Experiment Station. One of the objectives of this study is to investigate the relative quantity, quality, and rate of growth of sprout cherry on various sites within the oak-hickory and cove hardwood areas.

\section{Review of Literature}

Nuch of the research on the occurrence, quality, and silvical characteristics of black cherry has been done in northern Pennsylvania and southwestern New York. This is the area where black cherry, because of its superior size and abundance, has always occupied an important position in the forest economy. In this area, good black cherry is more frequently associated with the northern hardwood type, known locally as the "Allegheny hardwoods," which consists primarily of the sugar maplebeech-yellow birch type.

It has been observed that sprout cherry is generally of poorer stem form and more subject to heartwood rots than seedling-origin cherry (Campbell and Spaulding, 1942). Cherry sprouts are weakly attached to the parent stump, and are thus subject to breakage. Sprouts, except for those in the center of the sprout clump, grow too rapidly to undergo good natural pruning (Hough, 1937). Thus, seedlings are a much better source of growing stock for future sawtimber (Ostrom, 1937, 1938; Van Dersal, 1938).

Black cherry is capable of very rapid growth. Hough (1943) reports cherry attaining a diameter of 20 to 24 inches and a height of 80 to 100 feet in 60 years. The maximum height recorded is 129 feet; the tree was 258 years of age (Hough, 1949). The characteristic growth pattern is rapid early growth up to 60 years of age, followed by a marked slowdown.

For the northern Allegheny Plateau in Pennsylvania, Hough (1959) suggests zoning each forest tract to delineate those sites where black cherry production is practical. The zones outlined by this author are based primarily on those critical elevations above which glaze damage to cherry sapling and poles can be anticipated. Hough also points out that where cherry is associated with northern hardwood types, it is superior to that found in mixed oak stands, aspen-pin cherry type, pure hemlock type, or hemlock-white pine type. 
Since the occurrence of these types depends largely on slope position and aspect, it is difficult to conclude whether the poorer cherry is the result of site factors or of environmental conditions brought about by the composition of the stand. In the Allegheny National Forest 59 per cent of the area was found to be in sites favorable for black cherry development. The most favorable sites for black cherry regeneration were found to be moist, fertile, lower north- and east-facing slopes.

Ostrom (1938), working with repeatedly clearcut stands in northwestern Pennsylvania, noted that black cherry increased in proportion to the number of cuttings. The species was more abundant in secondgrowth stands than in uncut stands, and nearly dominated the thirdgrowth stands. He considered this change in stand composition to be unfortunate, since stump sprouts of this species suffer such high breakage and ice damage, and are generally of poor form.

With regard to growth, black cherry was found to outrank all other species in net board-foot production in the northern Allegheny Plateau. Second growth has reached merchantable size only in recent years. In young stands, black cherry seedlings were found mixed with the cherry sprouts, but the seedlings were generally shaded out by the fastergrowing sprouts (Hough, 1953).

\section{Location of Study Area}

The study areas of the present project were located in the West Virginia University Forest in Monongalia and Preston counties, in northern W'est Virginia. This 7,500-acre tract, completely cut over in 1924-25, now supports pole-sized sprout stands that are even-aged almost to the year.

The II.V.U. Forest is on Chestnut Ridge, the western-most ridge of the Allegheny Mountains. The land surface is hilly, but slopes are seldom steep or abrupt. Observations indicate that site index throughout this area depends far more heavily on aspect, slope position, and per cent slope than on chemical or physical properties of the soil.

Although black cherry is present throughout this area, it is not abundant. It rarely exceeds 20 per cent of the stand, and usually makes up much less. More often only a few stems are found per acre. The form of the bole is frequently crooked, consistently poorer in this respect than the boles of associated species. Hence, foresters in their silvicultural practices have been prone to disregard or even discriminate against cherry in favor of species with better-formed boles.

Early records of this area indicate that wild black cherry was an important tree in the original oak-hickory and cove forests, leading to the speculation that cherry could again contribute substantially to the forest economy. On this subject Maxwell (not dated), a local Nineteenth-Century historian, says: 
"In Monongalia County black cherry is the most valuable of the wild cherry family, and the only one of them that has ever contributed to the lumber industry. The wild cherry which grows here is of sufficient size to make it wanted at the sawmill. The lumber has always sold at a good price, and the furniture factories take it when it can be had. The trees (cherry) in most parts of the county were scattered in small numbers, when the first people came here. It has held its ground, but not in quantity as great as at first. The wood has never been as important here as it has in other places."

Furniture companies in various parts of the United States have indicated that West Virginia black cherry is entirely acceptable at their mills, and that the only factor that leads them elsewhere for supply is the limited amounts that West Virginia forests presently provide.

\section{Collection of Data}

Using aerial photographs, 69 one-fifth-acre plots were selected at random for a study of black cherry abundance, quality, and rate of growth. The following measurements were then obtained in the woods: aspect, slope position, and per cent slope. If cherry occurred on the plot, all trees larger than 4 inches dbh (diameter breast high) were measured to the nearest inch, and the species recorded. The four cherry trees nearest the plot center were evaluated for origin (sprout or seedling), number in sprout clump, crown position, and form and condition of bole.

The bole form and condition was rated on a point system. Trees rated Class 1, Class 2 or Class 3 were considered stems of potential sawtimber value. Class 1 cherries had no defect in the lower 16 -foot $\log$, and Class 2 cherries had only one minor defect in the lower $\log$. Trees in Class 3 had two or three minor defects in the first $\log$, but none serious enough to discount their value for lumber. Trees rated Class 4 or Class 5 were those which had a major defect or more than three minor defects, making them unsuitable for any use except mine props, fuel-, or pulpwood. When the defect was crook or sweep, the location of the defect was considered in evaluating the stem.

In addition, the rate of diameter growth of two upper-crown-class cherries and two other commercial species was measured for each plot. These other species were usually yellow-poplar, northern red oak, or cucumbertree. The measurements were made to compare the relative rate of cherry diameter growth with that of other species at each plot location.

In another phase of this study 300 additional black cherry trees, representing various aspects and slope positions between 1,100 and 2,550 feet elevation, were evaluated for breakage by ice, in an effort to determine the severity and boundaries of the glaze belt in northern West Virginia. 


\section{Analysis of Data}

Preliminary graphing of the clata for aspect, slope position, and per cent slope against basal area per acre for each plot indicated that aspect and slope position are closely related to total basal area. This suggests that basal area per acre is correlated with temperature and moisture conditions. Prerious ecological studies in oak types in W'est Virginia have shown the close correlation of composition and growth rate with aspect and slope position (Weitzman and Trimble, 1955; Carvell and Tryon, 1961).

The decrease in total basal area per acre as the drier aspects are approached is evident from the averages of the basal areas for the experimental plots, Table 1 .

Table 1. Average Basal Area (Souare Feet) and Numrer of Trees PER ACRE, BY ASPECT.

\begin{tabular}{|c|c|c|c|}
\hline & \multicolumn{3}{|c|}{ AsPECT } \\
\hline & $\begin{array}{l}\text { MoIst, COOL } \\
\text { NE. N, E }\end{array}$ & $\begin{array}{c}\text { INTERMEDLATE } \\
\text { NT, SE }\end{array}$ & $\begin{array}{l}\text { DRY, WARM } \\
\text { S, W, SWW }\end{array}$ \\
\hline $\begin{array}{l}\text { Basal Area per Acre } \\
\text { Trees per Acre }\end{array}$ & $\begin{array}{l}82.7 \\
268\end{array}$ & $\begin{array}{l}81.8 \\
326\end{array}$ & $\begin{array}{l}59.1 \\
270\end{array}$ \\
\hline
\end{tabular}

The average basal area for dry, warm sites was significantly different from that of the moist, cool sites and intermediate sites at the 1 per cent level. Likewise the difference between the number of trees per acre for intermediate sites was significant from the moist, cool sites and the dry, warm sites at the 1 per cent level.

When the basal area and number of trees per acre for the plots were averaged by slope position, the data in Table 2 were obtained. The differences in basal area among the three slope positions was found to be significant at the 1 per cent level. The differences in the number of trees per acre on the slope positions were significant at the 5 per cent level.

Table 2. Average Basal Area (Square Feet) and Average Numier of Trefes per Acre, Based on Slopf. Position.

\begin{tabular}{|c|c|c|c|c|c|c|}
\hline & \multicolumn{6}{|c|}{ SIOPE Posriton } \\
\hline & I.OWER & ONE-THIRD & MIDDLF & E ONE-THIRD & UPPER & ONE: THIRD \\
\hline $\begin{array}{l}\text { Basal Area per Acre } \\
\text { Trees per Acre }\end{array}$ & & $\begin{array}{l}76.5 \\
289\end{array}$ & & $\begin{array}{l}89.0 \\
309\end{array}$ & & $\begin{array}{l}70.5 \\
263\end{array}$ \\
\hline
\end{tabular}

To determine whether or not the basal area of black cherry per acre showed a definite correlation with the total basal area per acre, a regression was calculated with the form: 


$$
\text { Ycba }=\mathrm{b}_{0}+\mathrm{b}_{1} \mathrm{Xtba}
$$

where: Ycba $=$ total basal area of black cherry per acre,

Ytba = total basal area of all species per acre,

$b_{0}, b_{1}=$ numerical coefficients to be obtained from the data.

The analysis of variance showed that this regression was significant at the 1 per cent level. The regression equation was thus obtained:

$$
\text { Ycba }=0.354 \mathrm{Xtba}-17.758
$$

Using this regression equation the tabulation in Table 3 was made.

TAFLE 3.

\begin{tabular}{c|c}
\hline \hline Total Basal Area* Per ACre & Basal AreA* OF Black Cherry \\
\hline 60 & 3.482 \\
70 & 7.022 \\
80 & 10.562 \\
90 & 14.102 \\
100 & 17.642 \\
110 & 21.182 \\
\hline
\end{tabular}

* Square Feet

Efforts to relate the quality of black cherry to site factors showed no significant results, but per cent of black cherry trees in Classes i and $2\left(Y_{1}\right.$ and $\left.Y_{2}\right)$ was significantly related to the total basal area per acre. The regression equation for this relationship (significant at the l per cent level) is:

$$
\mathrm{Y}_{1} \text { and } \mathrm{Y}_{2}=0.727 \mathrm{Xtba}-19.835
$$

Through this regression equation the tabulation in Table 4 was obtained.

Diameter growth for the past decade of dominant trees was averaged by species for the various aspects and slope positions. Since the sample of dominant white oaks and cucumbertree was too small to give reliable averages, only those for black cherry, yellow-poplar and northern red oak are included in Table 5.

TABle 4.

\begin{tabular}{c|c}
\hline \hline Basal Area* per Acre & $\begin{array}{c}\text { Per Cent Black Cherry } \\
\text { (Form Classes 1 ANd 2) }\end{array}$ \\
\hline 60 & 23.8 \\
70 & 31.1 \\
80 & 38.3 \\
90 & 45.6 \\
100 & 52.9 \\
110 & 60.1 \\
\hline
\end{tabular}

*Square Feet 
Table 5. Diameter Growth, in Inches, During Past Decade.

\begin{tabular}{|c|c|c|c|c|c|c|}
\hline \multirow[b]{2}{*}{ SPECIES } & \multicolumn{6}{|c|}{ TOPOGRAPHIC POSITION } \\
\hline & $\begin{array}{l}\text { MoIST, } \\
\text { Clool }\end{array}$ & $\begin{array}{l}\text { INTER- } \\
\text { MEDIATE }\end{array}$ & $\begin{array}{l}\text { DRY, } \\
\text { WARMI }\end{array}$ & $\begin{array}{c}\text { LOWER } \\
1 / 3\end{array}$ & $\begin{array}{c}\text { MIDDLE } \\
1 / 3\end{array}$ & $\begin{array}{c}\text { UPPER } \\
1 / 3\end{array}$ \\
\hline Black Cherry & 3.2 & 2.7 & 2.5 & 2.4 & 2.8 & 2.3 \\
\hline Yellow-Poplar & 3.3 & 2.7 & --- & 2.9 & 2.9 & 2.9 \\
\hline Northern Red Oak & 2.4 & 2.9 & 2.9 & 2.3 & 2.3 & 2.4 \\
\hline
\end{tabular}

When the 300 trees were evaluated for glaze damage, it was found that this damage occurs on the cooler slopes above 1,850 feet elevation. On the warmer slopes there is no breakage below an elevation of 2,000 feet. Damage extends up to 2,550 feet, the highest elevation on the West Virginia University Forest. Within the glaze belt 22.4 per cent of the cherry showed moderate to severe breakage from past glaze storms. This figure does not seem high enough to restrict management for black cherry within the glaze zone.

\section{Discussion}

The basal area in 37-year-old stands varied from 36 to 124 square feet per acre, and was found to increase as the cooler, more moist aspects and positions were approached. The lowest basal areas were found on those sites with west, southwest, and south exposures and on the upperthird slope positions.

Most interesting in the basal area comparisons by aspect was the similarity of basal area of those sites usually thought of as moist and cool (northeast, north, and east) and those considered intermediate (northwest and southeast). Middle-third and lower-third slopes also have relatively similar stocking. The lower basal area of the lower-third slope positions, when compared to the middle-third, suggests that the former areas tend to be slightly understocked. This can possibly be attributed to the difficulty for regeneration to become established where competition from herbaceous vegetation and vines is most severe.

The total basal area of black cherry increases directly as the total basal area per acre increases. 'This indicates that the greatest amount of cherry is found on the more moist, cooler sites, and on the lower twothirds of the slopes. It is about equally distributed over these topographic positions. Based on the statistical analysis, the following comparisons of basal area and quality of black cherry can be derived (see Table 6) .

The significant relationship between the per cent of form Classes 1 and 2 cherries and basal area can be attributed to the benefits of heavy stocking on natural pruning. Much of the defect that lowered the quality rating of cherry boles to Classes 3,4 , and 5 was obviously attributable 


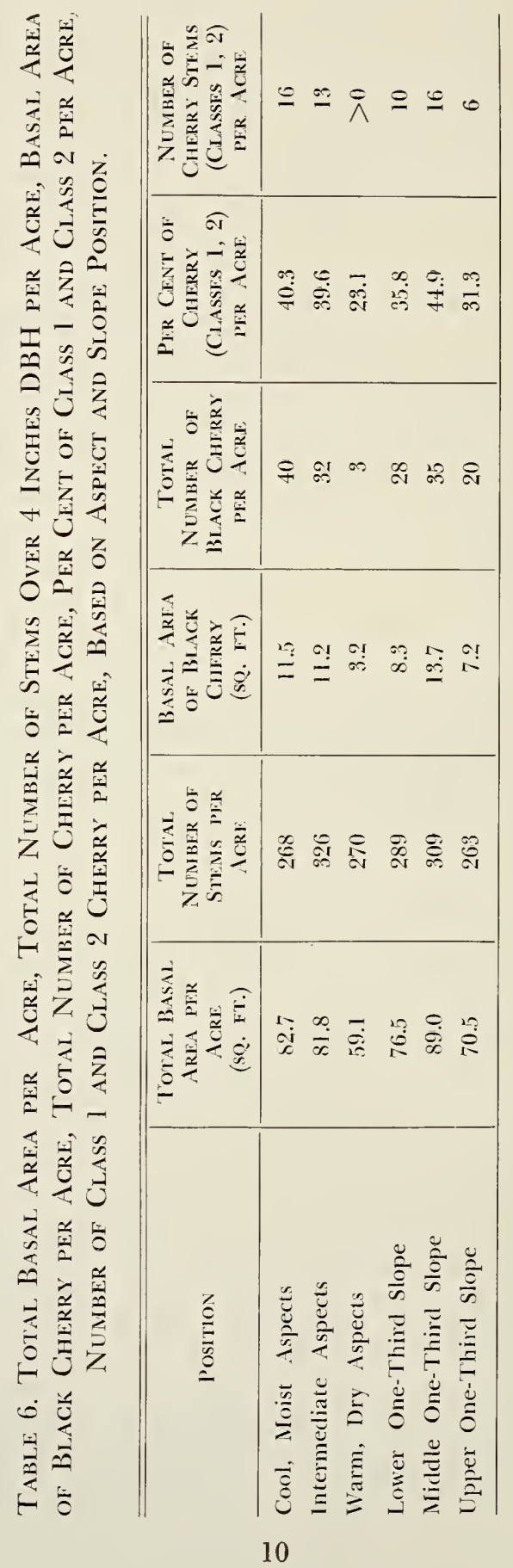


to poor pruning. Heavy, even stocking forces good natural pruning and reduces the number of high ascending branches that compete successfully with the main leader. This discourages forking and unusually heavy branches.

It is also likely that on the better sites-those with the higher basal areas-the height growth of cherry sprouts up through the largesapling stage does not greatly exceed that of associated species. Thus there is adequate crown competition to shade out the lower cherry branches during this important period of bole development. Competition from adjacent crowns inhibits the development of large limbs which develop heartwood and prune poorly. On the poorer sites, sprout cherry out-distances its associates in height growth up through the sapling stage, and thus develops coarse branches which leave large open wounds and rot pockets when they fall.

On poor sites where black cherry is standing above its associates, it is more subject to snow and glaze breakage (Carvell et al., 1957). Since it is not crowded by neighboring stems, ascending branches, competing for leadership, are more apt to survive and produce permanent forks. On all sites where scattered older black cherries tower above an even-aged crown canopy they are invariably broken by glaze, or by snow.

Conditions observed during this study suggest that the poorer form of sprout black cherry stands, when compared to those of seedling origin, can be attributed, at least in part, to the uneven distribution of stems in the seedling- and sapling-sized coppice stands. The stems in sprout stands occur in widely-spaced clumps. For many years these trees are inadequately hemmed-in by competing crowns to produce staight stems with small branches and good natural pruning.

The extent of butt rot in sprout cherry stands was not determined in this study, but will no doubt prove an important factor in reducing the merchantable volume of certain sprouts.

\section{Literature Cited}

Campbell, W. A., and P. Spaulding, 1942. Stand Improvement of Northern Hardwoods in Relation to Diseases in the Northeast. U. S. For. Ser. Allegheny For. Exp. Sta. Occas. l'aper No. 5.

Carvell, K. L., and E. H. Tryon, 1961. "The Effect of Environmental Factors on the Abundance of Oak Regeneration Beneath Mature Oak Stands." For. Sci., 7:98-105.

Carvell, K. L.., E. H. Tryon, and R. P. True, 1957. "Effects of Glaze on the Development of Appalachian Hardwoods." Jou. For., 55:130-132.

Hough, A. F., 1937. "Why Timber Stand Improvement?" Jour. For., 35:813-833.

Hough, A. F., 1943. "Methods of Harvesting Sawtimber from Forests in the High Plateau Section of Pennsylvania." Jour. For., 41:898-903.

Hough, A. F., 1949. "Deer and Rabbit Browsing and Available Winter Forage in Allegheny Hardwood Forests." Jour Wildlife Mangmnt., 13:135-141.

Hough, A. F., 1953. "Preliminary Recommendations for the Management of Black Cherry on the Northern Allegheny Plateau." Jour. For., 51:184-188.

Hough, A. F., 1959. "Zoning for the Nanagement of Black Cherry on the Allegheny Plateau." Jour. For., 57:353-357. 
Maxwell, H. (not dated). "The Vegetation Found by the Pioneers." History of Monongatia County, Morgantown, pp 21-25.

Ostrom, C. E., 1937. Tree Form and Defects in Young Besch-Birch-Maple-Hemlock Stands. U. S. For. Ser. Allegheny For. Exp. Sta. Tech. Note No. 14.

Ostrom, C. E., 1937. "Clear Cutting of Young Nortbern Hardwood Stands." Jour. For, 36:44-49.

Van Dersal, W. R., 1938. Native Woody Plants of the Umited States, Their Erosion Control and Wildlife Values. U. S. Dept. Agr. Misc. Publ. No. 303.

Weitıman, S., and G. R. Trimble, Jr., 1955. “A Capability Classification for Forest Land." Jour. Soil and Water Cons., I0:228-232.

Wray, R. D., 1952. Forest Statistics for If est V'irginia. Northeastern For. Exp. Sta. Forest Statistics Series: W. Va. No. 1. 

